\title{
Multiculturalism as a Reflection in the Decorative Motif in Malaysia Traditional Buildings
}

\author{
Norzalifa Zainal Abidin, ${ }^{1}$ Puteri Shireen Jahn Kassim, ${ }^{2}$ \\ Abu Dzar Samsudin, ${ }^{3}$ and Tengku Anis Qarihah Raja Abdul Kadir ${ }^{4}$ \\ Department of Applied Arts and Design \\ Kulliyyah of Architecture and Environmental Design \\ International Islamic University Malaysia \\ Jalan Gombak, 53100 Gombak, Kuala Lumpur \\ Corresponding Author: norzalifa@iium.edu.my
}

\begin{abstract}
Multiculturalism is under constant debate as to how it is linked to developing inclusive identity in the facades of public buildings: yet it must be rooted in overall local identity. The richness of this multiculturalism elements is reflected in the various motifs applied in the traditional public buildings. Influences of this Multiculturalism will also be discussed in this paper. The paper reviews a series of composition analyses of the motifs in the building components and elements of palaces, an aristocratic house and a mosque in Malaysia in order to study the composite elemental vocabulary based elements and the links to the local endemic Malay identity and traditional decoration motifs from the selected building elements; such as wall and ventilation panels, door leafs, staircases and balustrades are extracted $\mathrm{n}$ studied morphologically. Case study taken from Balai Besar Kedah, (1896) Istana Jahar (1887) Kota Bharu, Istana Bandar (1903) Kelang, Rumah Panglima Ghani Melaka and Masjid Tengkera Melaka (Malaysia). The motifs are broken down into constituent multicultural components and elements to show vocabulary and usage of colour which also reflect the symbolic meanings behind these motif compositions. The basic understanding of these elements are shown to reflect the multiculturalism richness and vocabulary used in these decoration motifs.
\end{abstract}

Keywords: Multiculturalism, traditional motifs, Malay identity and vocabulary, composition analyses

\section{Introduction}

Malaysia is a country that is rich with culture. The current Malaysia is made up of different type of ethnic group includes Malays, Chinese, Indian and the Native. In fact, different ethnic groups have their own history, culture, belief system, value and language. Although each ethnic is very much different from each other, there is a sense of unity among this ethnic (Essays,UK 2011). Malaysia is also separated to two islands, one is called Malay peninsula and the others are Sabah and Sarawak. The Malays are one of the earliest and dominant races, but they are mostly from Malay Peninsula. It is believing that the early religion or belief of the Malays at that time are of Hindu Buddhist by an archaeological evidence from 7th or 8th century temple-remains in the Bujang 
Valley (Hooker, V. M et al,2004). The arrival of Islam completes the displays on the ground floor and the next stage of Malaysia's history, the period of the famous $15^{\text {th }}$ century kingdom of Melaka.

The Malay peninsula is an area which are very strategic especially in its position as the centre of trading for the whole world. This led to the early assimilation of the Malays and its trading partner. The trader is from China, India and Arabs (Hooker, V. $\mathrm{M}$ et al,2004). This is one of the earliest forms of multicultural experience that the Malay and at its peak we could see a great civilisation of the Malays from Melaka which became the international trading and shipping area.

Then came the fall of Melaka by the invasion of Portuguese. This mark the start colonise era for Malay peninsula. These events is sort of a multicultural assimilation but in a forcing manner by the Portuguese towards the Malays. After Portuguese came the British. The British bring a softer approach towards colonising the Malay Peninsula, a very soft yet sly in gaining its trust from the Sultan (leaders of Malay people) at that time. The British brought labour worker from India and China which now became the citizen of Malaysia.

This chronological event that happened in Malay Peninsular does not only affect the people but it also affects the style of building that is being built at that time. The assimilation of culture from different races inclusive the artworks and architecture decoration elements would actually bring life to a new form of decorative motif in the Traditional building of Malaysia.

\section{Multiculturalism in Architecture and Arts}

'Culture' originates from the term 'cultivation', it is implying that one has 'grown' through experience and knowledge. Cultures are "value-guided systems. Values define cultural man's need for rationality, meaningfulness in emotional experience, richness of imagination, and depth of faith." (Ervin Laszlo, 1972). It could be said that culture is a process that any civilization would go through to be what it is today. Multiculturalism is the process of how one dominant culture would assimilate with a new kind of culture. According to Eagan, J. L. (2015) multiculturalism is that of cultures, races, and ethnicities, particularly those of minority groups, deserve special acknowledgement of their differences within a dominant political culture. In the case of Malays it is related to the acknowledgement of the Malays culture towards the other cultures. The uniqueness will focus onto the enhancement of Unity in Diversity decorative art elements particularly applied in the traditional buildings in Malaysia.

Architecture are the manifestation of the cultural context in which it resides. The form relationships of buildings and spaces act as a kind of "cultural marker" that can be read, likewise to the way one might read an information to describe its content. Joseph Esherick, Fellow of the American Institute of Architects, of Esherick, Homsey, Dodge and Davis in San Francisco states that,

"Real" architecture has an attachment to a larger reality that goes beyond architecture itself. Characteristics of the land, the attributes of the people, the economic basis of 
the building environment, range of uses, climate, culture-all are the real determinants ofform.

We can see that culture plays a very big role in determining architectural form. This would also include the architectural from of building that would have not one but multiple influence of culture in its design. The architecture of a building that has gone through a multi culture phase would see a hybrid of its design through form, structure and decorative elements. Yet the most polish part of a building that would cherish this diverse culture would clearly be the Decorative motif on a building.

\section{Assimilation of cultural expression in Decorative motifs in traditional buildings}

The architectural elements which contributed to decorative forms mostly relate to the building materials, construction methods, detailing and technology. This also includes the interior decoration elements which were and are still in use in these traditional buildings. Mostly are of traditional Malay art motifs and some have also somehow blend together with other motifs from outside of the region. The traditional Malay art and crafts are considered as part of thecultural product of the Malay people. However, some of these decorations were and are stillin use in parallel to the Islamic arts concept especially when they are applied to Islamicbuildings such as mosques. Further detail concept of the Malay art decorative motifs will behighlighted in the next section to relate the important connection between the Malay local artsand crafts with the Islamic Arts and the infusion of other cultural art elements especially as applied to the design of the traditional buildings. By identifying the semantic languages in these decorative elements via the formation of their compositions which are applied in the traditional buildings, we can clearly see that the infusion of the multiculturalism elements. These infusions are actually the unique elements in which the traditional buildings in Malaysia become significant heritage to the Malaysian people. The continuous search of the Malaysian architectural identity become more and more significant.

\section{Objectives}

The aim of this research is to see the multiculturalism reflection in the decorative motif in Malaysia traditional building in Malaysia.

The objectives of the study are as follows:

i) To identify the decorative elements in the traditional buildings in Malaysia (with selected case study)

ii) To analyze the different cultures that influence the decorative motifs in the selected traditional buildings in Malaysia.

\section{Methods}

For this research observation and visual analyses are made via site visits of the selected five case studies as earlier mentioned. Literature research and content analysis are obtained through related topics especially on Traditional Malay Architecture and arts of Malaysia. Some data are collected from other researches. Further site visits and 
observation studies of the selected five traditional Malay buildings in Malaysia were carried out. References were made with various analysis to the recorded measured drawings of IIUM heritage lab. Further identification of the semantic languages of the selected decorative motifs which applied onto the surfaces of these traditional buildings are showing the multi culture influences on the decorative motifs. In this paper 4 case studies are presented. The buildings are selected with the characteristics as public usage with 4 characters: i) 1 Assembly Hall, Palace (Balai Besar Kelantan) ii) 1 aristocrat house (Melaka) iii) 1 traditional Palace (Kelang) and iv) 1 masjid(Melaka).

\section{Discussion}

In this research four traditional buildings were chosen as case studies. These case studies include variety of building typology: palaces, aristocratic house and mosque. In this research, the two palaces which are chosen: Istana Balai Besar Kelantan and Istana Bandar,Kelang. Both aristocratic house and masjid include the Rumah Panglima Ghani, Melaka and Masjid Tengkera Melaka. The timeline of the building range from 1828 to 1899. During this time much influences of other cultures such as the Chinese, Indians, European decorative motifs can be seen in these buildings.

The first building chosen is Masjid Tengkera, Melaka 1828 which was designed by the village people that lives around the mosque which include Keeling village, Tanjung village and Lapan village. The third is Istana Balai Besar Kelantan built in 1844 designed by Mohamad Salleh. The Fourth building is Rumah Panglima Ghani which was built in 1894 and designed by a group of artisans who were Manaf Bopeng, Mahmud Kelanta, Pendek Pendekar and Sahal b. Junit. Lastly, the Istana Bandar built in 1899, was designed by Arthur Hubback.

All selected buildings were chosen because they are rich with decorative motifs at multiple parts of these buildings. The selected areas which were chosen consist of the indoor and outdoor decorative elements. Indoor decorative motifs which were chosen are the above framed door (ambang pintu) and the s (tiang). The outdoor decorative chosen is fascia board (papan cantik), window decoration (hiasan tingkap) and staircase (tangga). All are shown in the following tabulations.

\begin{tabular}{|c|c|c|c|c|c|}
\hline Building & ISTANA & ANDAR, & 1899) & & \\
\hline Position & Indoor & Outdoor & Indoor & Outdoor & Outdoor \\
\hline Component & Column & Staircase & $\begin{array}{l}\text { Ambang } \\
\text { Pintu }\end{array}$ & Papan Cantik & $\begin{array}{l}\text { Kekisi } \\
\text { Tingkap }\end{array}$ \\
\hline
\end{tabular}




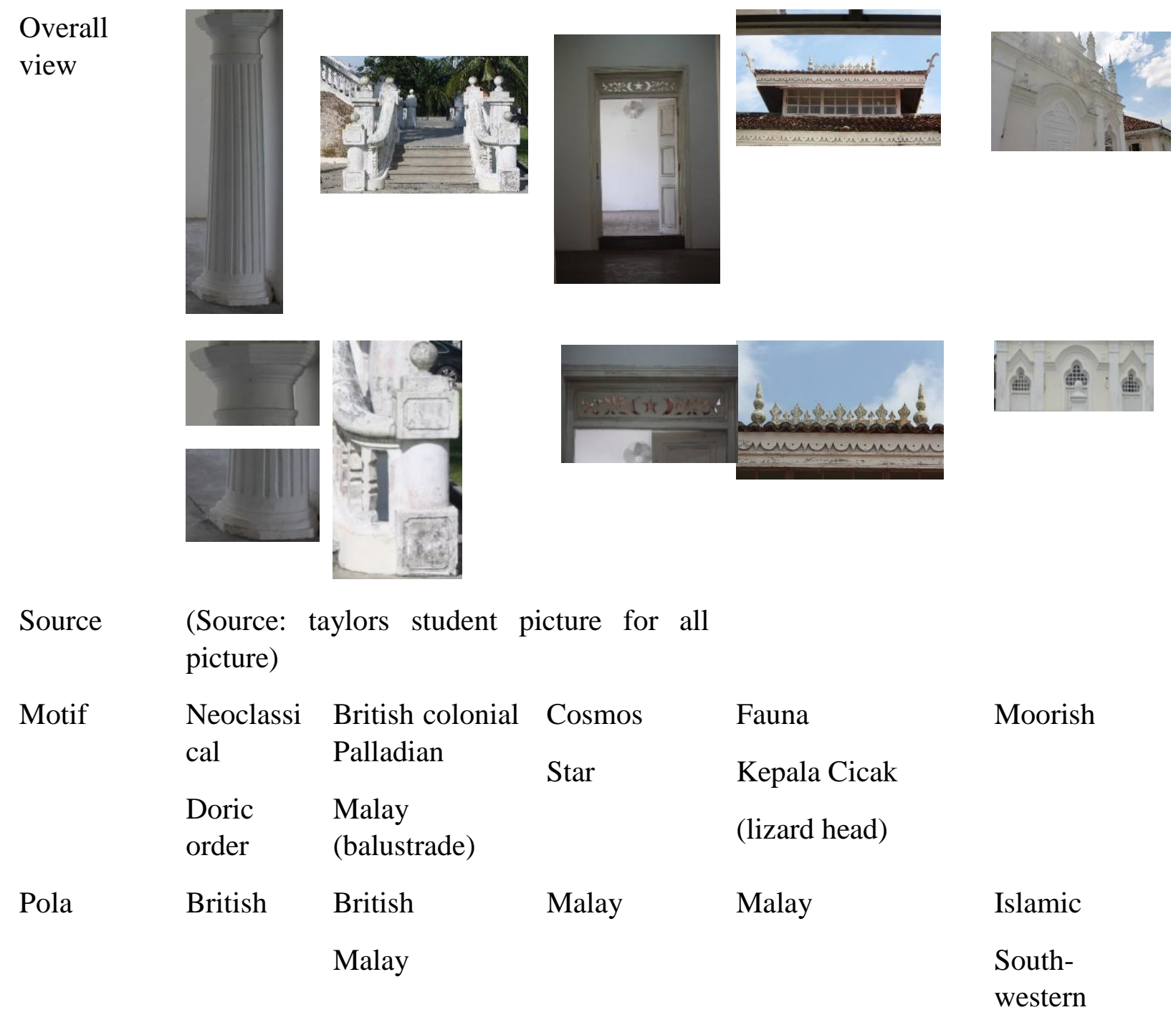

Figure 1: Istana Bandar building component analysis

Istana Bandar is a Malay palace that is built on 1903. During this time, the British had been a very strong influence towards the Malay society be it its politic or infrastructure. The Istana Bandar had a total of four significant influences in the art decoration elements, which are the Malay, British colonial, Moorish Islamic and Chinese elements. Based on the case study the column designs had influence from a British colonial architecture specifically towards Neoclassical style. As seen from the following Table 2, the column structure uses a Neoclassical Doric order which came from Greek classical order. In the next tabulation, Table 2, we can see the Masjid Tengkera analyses.

\begin{tabular}{|c|c|c|c|c|c|}
\hline Building & \multicolumn{5}{|c|}{ MASJID TENGGKERA, TENGKERA (1828) } \\
\hline Position & Outdoor & Outdoor & Indoor & Outdoor & Indoor \\
\hline Component & Column & Staircase & $\begin{array}{l}\text { Ambang } \\
\text { Pintu }\end{array}$ & Papan Cantik & $\begin{array}{l}\text { Kekisi } \\
\text { Tingkap }\end{array}$ \\
\hline
\end{tabular}




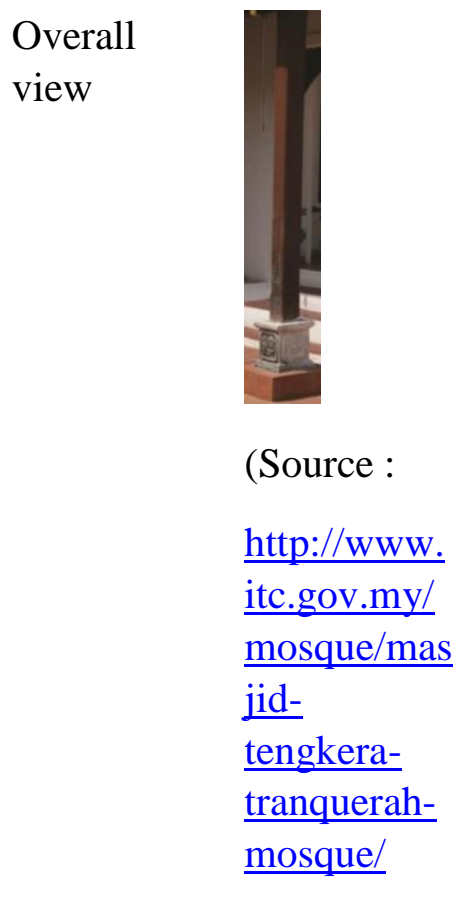

$15 / 8 / 2018)$

Focus

Study
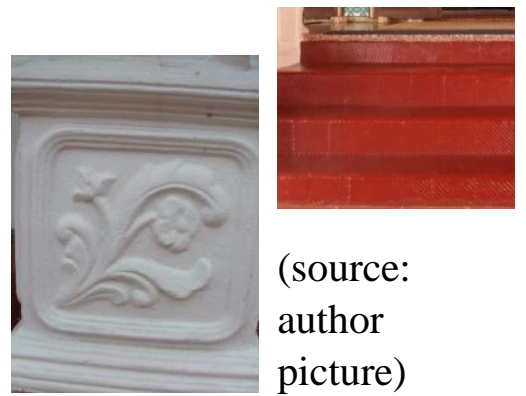

(source:

author

picture)

(source:

author

picture)

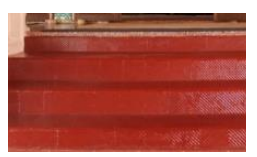

(Source:

httpekstasici nta.blogspot.

com 201210

masjid-

tengkeramelaka.html

14/8/2018)
Motif

European

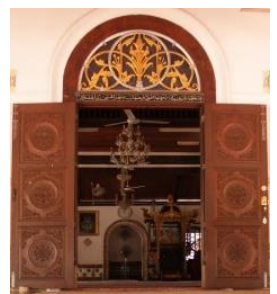

(Source:

httpekstasicint

a.blogspot.co

m201210masj

id-tengkera-

melaka.html

14/8/2018)

(Source :

https://www.123r

f.com

/photo_37998047

_tranquerah-

mosque-or-

masjid-tengkera-

located-in-

malacca-town-it-

was-built-in-

1728-and-be-the-

oldest-.html

$15 / 8 / 2018)$

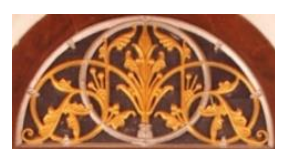

(source:

author

picture)

(source:author

redrawn)
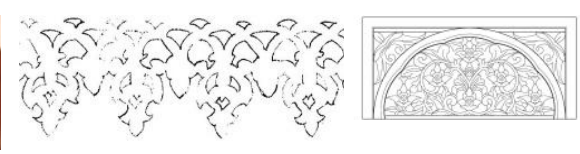

(source:

author

picture)

Floral Daisy

Pola

Eropah

China

Malay

Malay

Malay

\section{Figure 2 :Masjid Tengkera Building Component Analysis}

Masjid Tengkera was built on 1828. Masjid Tengkera is one of the earliest mosques in Malay Peninsula. Masjid Tengkera had a total of three cultural influences which are the Malay, Europe and Chinese. The column of Masjid Tengkera had influence of European motifs which can be seen at its pedestal area which have a Daisy flower motif. Next, is the Ambang Pintu which has a Malay motif of Sulur Kacang. The Papan Cantik is the next motif which have a Pucuk Rebung motif. Lastly the Arabesque motif can be seen on the window of area of the building. Next, in Table 3, is the analyses of the Istana Jahar. 


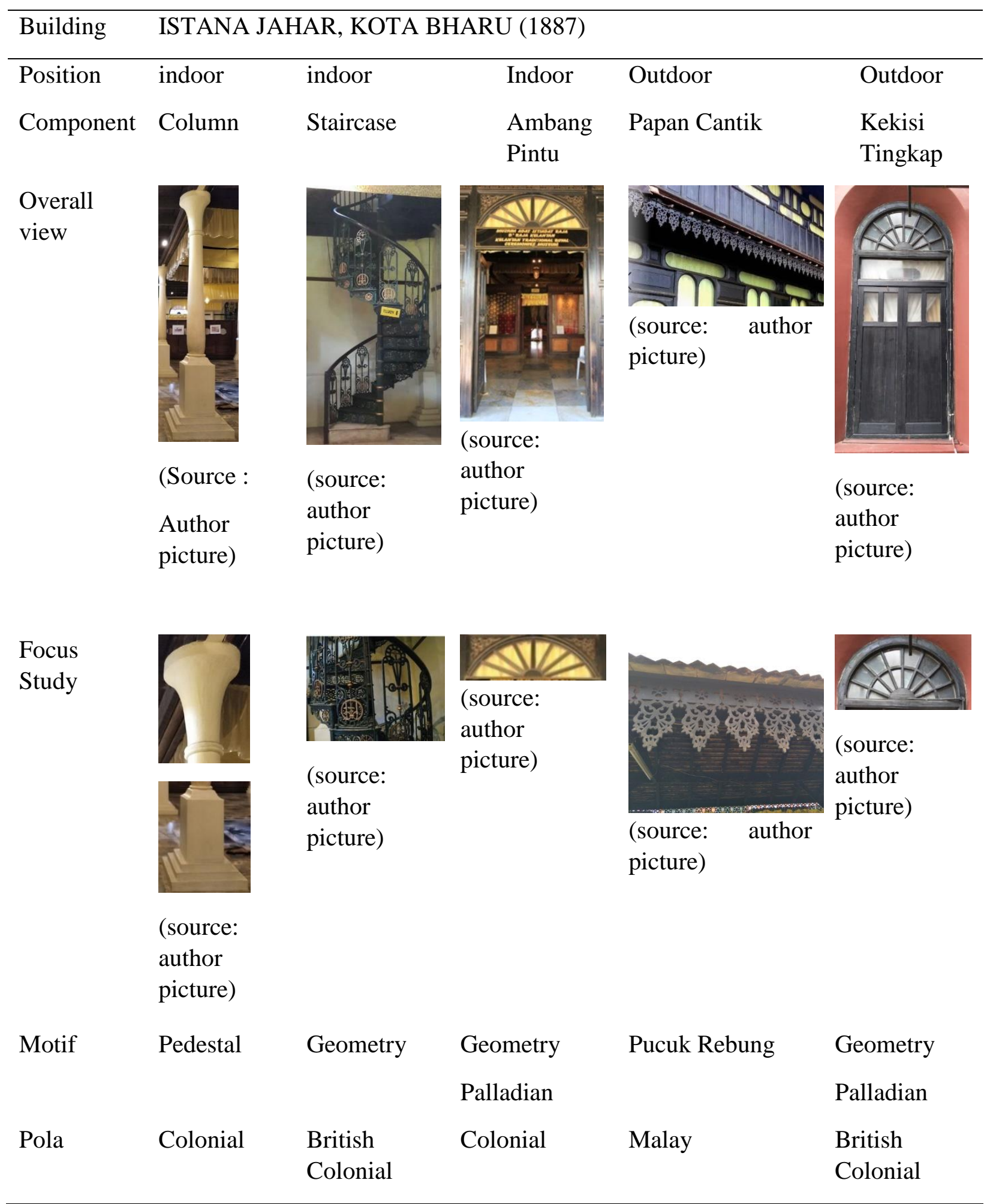

\section{Figure 3 :Istana Jahar Building Component Analysis}

Istana Jahar was built on 1887. The building had a total of 2 motifs which are British colonial and Malay. Its column has a pedestal that had Neoclassical architecture style. The staircase of Istana Jahar also had a British colonial influence but with a regency 
motif. Both its window and door had a Palladian motif. Lastly, its Papan cantik (fascia board) has a pucuk rebung motif.

\begin{tabular}{|c|c|c|c|c|c|}
\hline Building & UMAH D & NG ABDU & GHANI, MER & IMAU (1894) & \\
\hline Position & Indoor & Outdoor & Indoor & Outdoor & Outdoor \\
\hline Component & Column & Staircase & $\begin{array}{l}\text { Ambang } \\
\text { Pintu }\end{array}$ & Papan Cantik & Kekisi Tingkap \\
\hline $\begin{array}{l}\text { Overall } \\
\text { view }\end{array}$ & $\begin{array}{l}\text { (Source:http } \\
\text { ://lukisanter } \\
\underline{\text { ukur.blogsp }} \\
\underline{\text { ot.com/200 }} \\
\text { 9/10/ } \\
\text { 15/8/2018 }\end{array}$ & 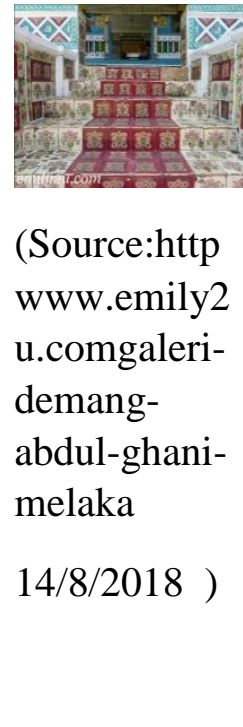 & $\begin{array}{l}\text { (Source:httpsp } \\
\text { enselpatahtunt } \\
\text { eja.blogspot.c } \\
\text { om } \\
\text { 201610terpes } \\
\text { ona-dengan- } \\
\text { keindahan- } \\
\text { senibina.html } \\
\text { 14/8/2018) }\end{array}$ & $\begin{array}{l}\text { (Source:httpw } \\
\text { ww.emily2u.co } \\
\text { mgaleri- } \\
\text { demang-abdul- } \\
\text { ghani-melaka } \\
\text { 14/8/2018) }\end{array}$ & $\begin{array}{l}\text { (Source : } \\
\text { httpthatsofarah. } \\
\text { comFrumah- } \\
\text { demang-haji- } \\
\text { abdul- } \\
\text { ghanifdx_switc } \\
\text { her=true14/8/20 } \\
\text { 18) }\end{array}$ \\
\hline $\begin{array}{l}\text { Focus } \\
\text { Study }\end{array}$ & $\begin{array}{l}\text { (same as } \\
\text { above) }\end{array}$ & $\frac{5}{600}$ & $\begin{array}{l}\text { covereo } \\
\begin{array}{l}\text { (same as } \\
\text { above) }\end{array}\end{array}$ & $\begin{array}{l}\text { (Source:http://t } \\
\text { hatsofarah.com } \\
\text { /rumah- } \\
\text { demang-haji- } \\
\text { abdul- } \\
\text { ghani/?fdx_swi } \\
\text { tcher=true } \\
\text { 14/8/2018) }\end{array}$ & 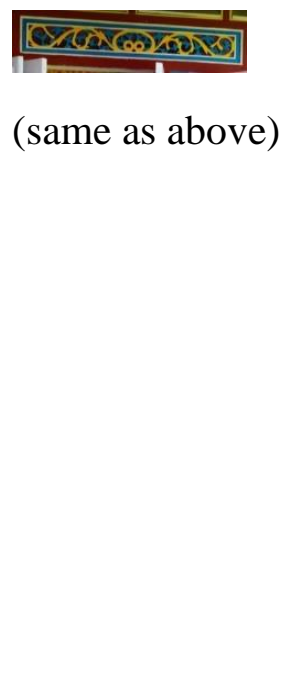 \\
\hline
\end{tabular}

$\begin{array}{lllll}\text { Motif } & \text { Sulur paku } & \begin{array}{l}\text { Peony } \\ \text { flower }\end{array} & \begin{array}{l}\text { Bunga bayam Kepala cicak } \\ \text { peraksi }\end{array} & \text { Bunga peraksi } \\ \text { Geometry } & \text { (side view) } & & \\ \text { Naga emas } & \text { Cempaka } & & \\ \text { Kepala } & \text { flower } & & \\ \text { cicak } & & \end{array}$




$\begin{array}{ccccc} & \begin{array}{l}\text { Peony } \\ \text { flower } \\ \text { Pola }\end{array} \text { China } & \text { Chinese Malay } & & \\ & \text { Malay } & & & \\ \end{array}$

\section{Figure 4:Rumah Demang Abdul Ghani Building Component Analysis}

Rumah Demang Abdul Ghani was built on 1894. The building had a total of 2 motifs which is Malays and Chinese. The column of this building had a fusion influence of both Malay and china. While the staircase had china peony flower motif and Cempaka flower. Its door and window both had malay flower motif of Bayam peraksi flower while its papan cantic (fascia board) had a kepala cicak motif (lizard head).

From the table analysis there are three major culture influences which are clearly identified in the decorative elements. The obvious decorative elements are of the influences of the Malay, British Colonial, and Chinese. The culture with the most influence is clearly the Malays. The second most is the British colonial and lastly Chinese. Each building has at least more than one motif. These decorative elements in these traditional buildings had a very rich multiculturalism in its decorative elements.

\section{Conclusion}

The multiculturalism in the decorative elements are seen as a strong significant evidences which show the uniqueness of the diverse influences of cultures. These diverse elements infused together whereby they become the signs of the Unity in Diversity concept. The evidences reflected in these decorative elements are also seen as the rich cultural diversity in Malaysia. The continuous search of Malaysia identity in any buildings are now becoming crucial. However so, the infused multicultural decorative elements can be applied as strong identities similar to these traditional buildings with the reflection of the diverse and infused decorative motif elements. These infusions of the cultural elements are the rich heritage for the Malaysian traditional buildings. Thus, to enhance the identity of the Malaysian heritage, a similar approach of the diverse application of the artworks can be also applied in the new modern Malaysian buildings. The true functions of the decorative elements should be fully understood and the decoration motifs should be correctly applied to prevent wastage and inappropriate usage and application in any buildings. The researchers are now in the midst of building up a collective database to record selected case studies, in reflection to the diverse multicultural decorative elements for future referral.

\section{Acknowledgement}

The authors would like to acknowledge the Transdisciplinary Research Fund (TRGS1603-001-0001- Characterization of Rules of Malay Architectural Language) from Ministry of Higher Education for the support of this research. 


\section{References}

Essays, UK. (November 2013). Malaysia Is A Multicultural Society Media Essay. Retrieved from https://www.ukessays.com/essays/media/malaysia-is-a-multiculturalsociety-media-essay.php?vref=1

Hooker, V. M., \& Osborne, M. E. (2004). A short history of Malaysia: Linking east and west. St. Leonards, N.S.W.: Allen \& Unwin.

Ervin Laszlo (1972) The Systems View of the World, New York: Georger Braziller, Inc., 1972, 101.

Eagan, J. L. (2015, August 31). Multiculturalism. Retrieved October 25, 2018, from https://www.britannica.com/topic/multiculturalism

Norzalifa Zainal Abidin, Reminiscing the Aesthesic and True Functions of Decoration in Masjid, 2018, Noor Publishing

\section{Photo Credits}

\section{Rumah Panglima Ghani}

RUMAH DEMANG ABDUL GHANI @ PENGHULU MAT NATAR. (1970, January 01). Retrieved August 15, 2018, from http://fairusmamat.blogspot.com/2012/01/rumahdemang-abdul-ghani-penghulu-mat.html

Terukur, L. (1970, January 01). LUKISAN TERUKUR C5333. Retrieved August 15, 2018, from http://lukisanterukur.blogspot.com/2009/10/

Demang Abdul Ghani Gallery. (2017, November 20). Retrieved August 14, 2018, from https://en.wikipedia.org/wiki/Demang_Abdul_Ghani_Gallery

Rumah Penghulu Md. Natar Paling Cantik Di Malaysia... (2016, October 15). Retrieved August 14, 2018, from https://penselpatahtunteja.blogspot.com/2016/10/terpesonadengan-keindahan-senibina.html

Galeri Demang Abdul Ghani, Melaka. (2013, June 26). Retrieved August 14, 2018, from https://www.emily2u.com/galeri-demang-abdul-ghani-melaka/

Rumah Demang Haji Abdul Ghani. (2014, January 25). Retrieved August 14, 2018, from http://thatsofarah.com/rumah-demang-haji-abdul-ghani/?fdx_switcher=true 


\section{Istana Bandar}

Shan, J. (2018, October 9). Importance of Jade in Chinese Culture. Retrieved August 19, 2018, from https://www.thoughtco.com/about-jade-culture-629197

Moorish architecture. (2018, October 28). Retrieved August 19, 2018, from https://en.wikipedia.org/wiki/Moorish_architecture

Lee, V. (2015, March 04). Methods Of Documentation And Measured Drawing (Istana Bandar). Retrieved August 15, 2018, from https://www.slideshare.net/vickylee24/methods-of-doumentation-and-measureddrawing-istana-bandar

\section{Istana Jahar}

Baharudin Jalil, Norwina Mohd Nawawi, Shamsuri Mohammed, Yang Kiang Loo, Zabidah Ahmad. (1976). Istana Jahar Kota Bharu Kelantan, Johor: KALAM, Universiti Teknologi Malaysia

\section{Masjid Tengkera}

RUSLAN, M. S., (dll.). (1980). KAJIAN LUKISAN TERUKUR MASJID TENGKERA. Bandar Melaka, Melaka: KALAM, Universiti Teknologi Malaysia

Masjid Tengkera (Tranquerah Mosque). (n.d.). Retrieved August 15, 2018, from http://www.itc.gov.my/mosque/masjid-tengkera-tranquerah-mosque/

Ekstasi, S. (1970, January 01). Masjid Tengkera, Melaka. Retrieved August 14, 2018, from http://ekstasicinta.blogspot.com/2012/10/masjid-tengkera-melaka.html

Tranquerah Mosque or Masjid Tengkera, located in Malacca Town,.. (n.d.). Retrieved August 15, 2018, from https://www.123rf.com/photo_37998047 tranquerah-mosqueor-masjid-tengkera-located-in-malacca-town-it-was-built-in-1728-and-be-the-oldest$\underline{. h t m l}$ 